\title{
Krill diel vertical migration fine dynamics, nocturnal overturns, and their roles for aggregation in stratified flows
}

\author{
M. Sourisseau, Y. Simard, and F.J. Saucier
}

\begin{abstract}
A set of high-resolution observations on short-term dynamics of krill diel vertical migrations (DVM) in the St. Lawrence Estuary are presented here, including vertical mass transfer measurements from multifrequency echosounding coupled with stratified net sampling and tracers of individual vertical movements from stomach pigments over a $72 \mathrm{~h}$ period. The data set is supplemented by vertical migration speeds and biomass diel patterns from ADCP (acoustic Doppler current profiler) time series lasting up to 3 months. All krill always rapidly migrated to the surface in synchrony at sunset. Soon after the ascent, fed krill started to swim downward. A scattering layer was then formed at their daytime depth with sometimes a significant backscatter at intermediate depths, especially around midnight. A reorganisation in the upper water column then occurs, likely for a predawn feeding bout. At dawn, the krill mass still feeding in upper water column synchronously swam downward to their daytime depth. This nocturnal asynchronous vertical behaviour, conforming to the DVM hunger-satiation hypothesis, repeated between August and October in two different years, the DVM timing being determined by day length.
\end{abstract}

Résumé : Un ensemble d'observations à haute résolution de la dynamique à court terme des migrations verticales nycthémérales (MVN) du krill dans l'estuaire du Saint-Laurent est présenté. Il incorpore des mesures de transfert de masse sur la verticale à partir d'échosondages multifréquences couplés à l'échantillonnage des strates au filet à nappe et le suivi des mouvements verticaux individuels par des mesures de pigments stomacaux sur une période de 72 h. Des séries temporelles des patrons circadiens des vitesses verticales de migrations déterminées à l'aide d'un ADCP (« acoustic Doppler current profiler »; profileur de courant acoustique à effet Doppler) complètent les mésures sur une période allant jusqu'à 3 mois. L'ensemble du krill migre toujours rapidement et en synchronie jusqu'en surface lors du coucher du soleil. Peu de temps après l'ascension, du krill nourri commence à nager vers le bas, ce qui se poursuit avec une intensité notable jusqu'au milieu de la nuit. Il forme alors une couche acoustique de rétrodiffusion à sa profondeur diurne, ce qui engendre une distribution verticale nocturne bimodale, souvent accompagnée de densités acoustiques notables aux profondeurs intermédiaires, particulièrement au milieu de la nuit. Une réorganisation dans la partie supérieure de la colonne d'eau survient ensuite, vraisemblablement pour une dernière période d'alimentation avant l'aube. A l'aube, la masse de krill s'alimentant toujours dans la partie supérieure de la colonne d'eau nage en synchronie vers sa profondeur diurne. Ce comportement vertical nocturne asynchrone, conforme à l'hypothèse de faim-satiété de la MVN, s'est répété entre les mois d'août et d'octobre à deux années différentes, la synchronisation de la MVN dépendant de la durée du jour.

\section{Introduction}

In his review of diel vertical migrations (DVM), Pearre (2003a) points out that detecting vertical migrations requires tracking not only mass transfer on the vertical with a temporal resolution that is high enough to adequately cover the diel changes and the fine nocturnal processes, such as the so- called midnight sinking or dawn rise, but also the interchanges of individuals. Under the hunger-satiation hypothesis of Pearre (2003a), the DVM is asynchronous within the population: animals leave the surface waters during the night as soon as they are satiated and may go back for a second meal before dawn after digesting their early-night meal (e.g., Simard et al. 1985). Such behaviour often results in bimodal

Received 16 August 2006. Accepted 8 November 2007. Published on the NRC Research Press Web site at cjfas.nrc.ca on 26 February 2008.

J19487

M. Sourisseau ${ }^{\mathbf{1}, \mathbf{2}}$ and Y. Simard. Institut des Sciences de la Mer, Université du Québec à Rimouski, 310 allée des Ursulines,

P.O. Box 3300, Rimouski, QC G5L 3A1, Canada; and Institut Maurice-Lamontagne, Fisheries and Oceans Canada, 850 route de la Mer, P.O. Box 1000, Mont-Joli, QC G5H 3Z4, Canada.

F.J. Saucier. Institut des Sciences de la Mer, Université du Québec à Rimouski, 310 allée des Ursulines, P.O. Box 3300, Rimouski, QC G5L 3A1, Canada.

${ }^{1}$ Corresponding author (e-mail: Marc.Sourisseau@ifremer.fr).

${ }^{2}$ Present address: IFREMER, DYNECO, Centre de BREST, B.P. 70, 29280 Plouzané, France. 
vertical distributions during the night (Pearre 1979). Patchiness and advection are additional constraints adding variability that complicates proper in situ detection. Understanding this DVM fine dynamics is not only a relevant academic question of ecosystem dynamics, but also fundamental for comprehensive understanding of mesoscale dispersion and organisation of the biomass under the vertically structured currents in the ocean, namely for the formation and maintenance of aggregations in particular areas that are sought by predators, such as baleen whale feeding grounds.

Three-dimensional (3D) circulation at tidal and other frequencies interacting with abrupt bathymetric features combined with the behaviour of zooplankton on the vertical are key players in aggregation processes (Genin et al. 1994; Mackas et al. 1997; Genin 2004). This is especially evident in stratified dynamic environments and flows such as estuaries (Kimmerer and McKinnon 1987; Roman et al. 2005). Simard et al. (1986a) and Runge and Simard (1990) attributed krill aggregation at the head of the St. Lawrence Estuary to the interaction between the deep-flow import of the strong two-layer estuarine circulation and the krill DVM, which they called an "estuarine pumping system". However, the horizontal distribution of macrozooplankton exhibits a high variability in response to fluctuations in the strength of the aggregation processes. This was evidenced in the St. Lawrence Estuary where dense krill concentrations exhibit an important spatial and temporal variability at mesoand smaller scales $(<\sim 100 \mathrm{~km}$ or $<$ months) (Simard and Lavoie 1999; Sourisseau et al. 2006). DVM plasticity and asynchronous features (Pearre 2003a, 2003b) should thus modulate the intensity of the aggregation-dispersion processes and the horizontal organisation. DVM variability at different time scales is well known for several zooplankton species, and among the modulating factors are light (Boden and Kampa 1967; Kaartvedt et al. 1996; Pearre 2003b), thermocline, halocline, and oxycline (Sameoto 1980; Spicer et al. 1999), physiological condition (Tarling 2003), food and predator distribution, and individual variability (Price 1989; Onsrud and Kaartvedt 1998; Tarling et al. 2002). Such dynamics should explain the following paradigm for the St. Lawrence Estuary. Coupled physical-biological models, including a two-dimensional (2D) model of the Estuary and laterally averaged current field (Zakardjian et al. 1999) and a 3D model (Sourisseau et al. 2006), concluded that the aggregation of vertically migrating zooplankton in the Estuary can not be generated if the organisms spend more than $6 \mathrm{~h}$ in the outflowing surface layers. However, field observations show that euphausiids are present in the surface layer $(0-40 \mathrm{~m})$ throughout the night (Simard et al. 1986b), and therefore, the two-layer "estuarine pumping system" suggested by Runge and Simard (1990) alone appeared insufficient to explain persistent krill accumulation at the head of the channel (e.g., Simard et al. 2003) if the animals stay in the surface layer overnight.

This krill aggregation constitutes the heart of the baleen whale feeding ground of the Saguenay - St. Lawrence Marine Park (Simard and Lavoie 1999). Krill DVM pattern and variability need to be accurately defined at the fine scale to correctly explain the observed distribution in the St. Lawrence system as a result of the combination of the vertical distribution with the two-layer circulation. The present work is an effort to estimate the detailed fine diel variability of krill vertical distribution. A suite of acoustical and stratified net sampling and pigment-tracing methods is used to examine mass transfer, individual interchanges, and migration speed on the vertical with high resolution. The average DVM pattern is combined with simulated currents at the mouth of the Estuary provided by the 3D regional circulation model (Saucier et al. 2003) to understand the actual dynamic of krill pumping in the Estuary. A great part of the discrepancy between the assumed process of krill aggregation in the Estuary and the simulated results is clarified.

\section{Materials and methods}

Intensive sampling was carried out aboard of the $\mathrm{R} / \mathrm{V}$ Coriolis II on 3-7 September 2003 on the north slope of the Laurentian Channel in the St. Lawrence Estuary (Fig. 1), on the entrance path of the regional krill aggregation at the channel head (cf. Lavoie et al. 2000). Zooplankton sampling was done with a $1 \mathrm{~m}^{2}$ Bioness $^{\mathrm{TM}}$ (Open Seas Insrumentation, Inc., Musquodoboit Harbour, Nova Scotia, Canada) with $1 \mathrm{~mm}$ mesh size, targeting larger zooplankton species and minimizing possible phytoplankton retention in the collector. The vertical strata were set to four layers representing different hydrodynamic conditions (0-20, 20-40, 40-100, and $100-150 \mathrm{~m})$. Short tows $(\sim 15 \mathrm{~min})$ were used to minimize krill stomach pigment degradation and the stress imposed to the organisms. The profiling frequency was slightly above $1 \cdot \mathrm{h}^{-1}$, and the zooplankton samples were frozen on board at $-80{ }^{\circ} \mathrm{C}$. The zooplankton identification in the laboratory was done as follows: for organisms larger than $10 \mathrm{~mm}$, the whole sample or a fraction with a minimum of 20 euphausiids was analyzed; for smaller zooplankton, mainly consisting of calanoid copepods, the minimum subsample size was fixed to 100 organisms. Four main zooplankton groups were observed (Meganyctiphanes norvegica, Thysanoessa raschi, Calanus sp., and Themisto libellula), but only euphausiids, which dominated, are considered in this paper.

Stomach pigment measurements were made on the two euphausiids species $M$. norvegica and T. raschi. For each species, a maximum of 20 and a minimum of five living organisms were sorted under artificial light immediately after the net retrieval on board. These organisms were then rapidly frozen at $-80{ }^{\circ} \mathrm{C}$ to avoid significant degradation of the chlorophyll inside the stomach. The laboratory analyses were then made within 2 months after the cruise. The organisms were thawed $(<5 \mathrm{~min})$, and their stomachs were extracted under the microscope, placed in groups of five into $5 \mathrm{~mL}$ of acetone $(90 \%)$, ground up, and left at $4{ }^{\circ} \mathrm{C}$ in dark for 14-16 h pigment extraction. Then, the chlorophyll $a$ concentrations were estimated with a Turner fluorometer (model TD-700; Turner BioSystems, Sunnyvale, California) following a method without acidification (Welschmeyer 1994). The fluorometer calibration was specific for chlorophyll $a$ estimation (Arar and Collins 1997).

Temperature and salinity were measured with a conductivity-temperature-depth meter (CTD; model SBE 19; Sea-Bird Electronics, Inc., Bellevue, Washington) mounted on the Bioness ${ }^{\mathrm{TM}}$. In situ fluorescence was measured with a fluorometer (model WS3S; Wetlabs, Philomath, Oregon). Additional profiles were obtained with another 
Fig. 1. Location of the sampling area in the St. Lawrence Estuary. The ship followed the $160 \mathrm{~m}$ isobath during the sampling. Stars indicate the positions of the acoustic Doppler current profiler (ADCP) moorings. The line on the upper panel shows the cross section of the numerical circulation model separating the Estuary from the Gulf that is used for the krill import simulations.

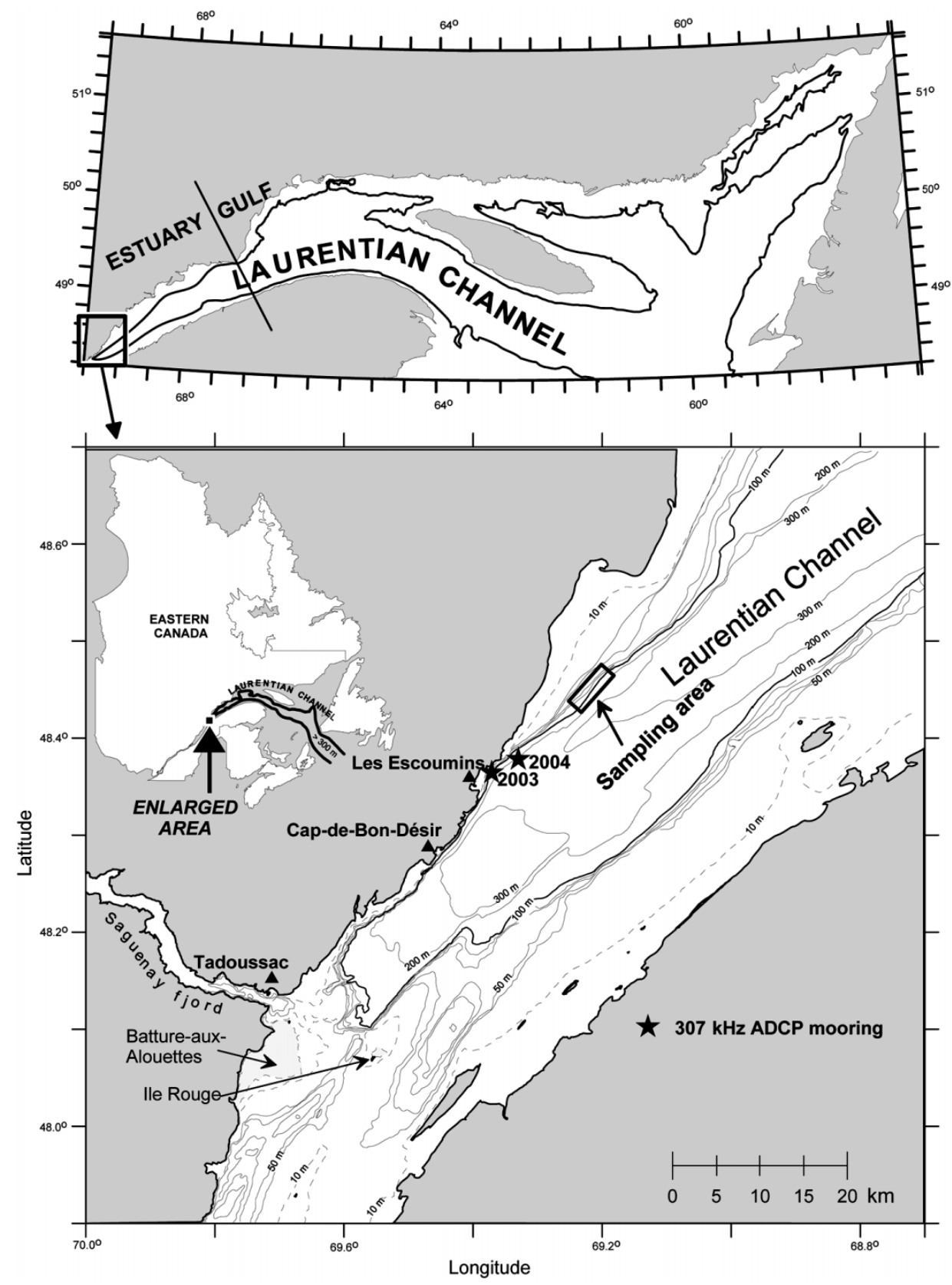

CTD (model SBE 19; Sea-Bird Electronics, Inc.) with oxygen and fluorescence sensors mounted on the rosette. One rosette profile was made after every two Bioness ${ }^{\mathrm{TM}}$ tows. Water samples were collected at four depths $(5,10,20$, and $50 \mathrm{~m}$ ) with Niskin bottles, and $250 \mathrm{~mL}$ were filtered on $\mathrm{GF} / \mathrm{F}$ filters. The filters were then frozen at $-80{ }^{\circ} \mathrm{C}$. The laboratory analyses were made within 2 months after the cruise. The chlorophyll $a$ was extracted in $10 \mathrm{~mL}$ of acetone $(90 \%)$ and processed as described above for the stomachs.

\section{Acoustics measurements}

The hull-mounted $156.3 \mathrm{kHz}$ acoustic Doppler current profiler (ADCP; WH Ocean Surveyor, $30^{\circ}$ tilted beam axis; Teledyne RD Instruments, Inc., Poway, California) was used to obtain current velocity and zooplankton backscatter intensity. The vertical resolution was set to $5 \mathrm{~m}$ for 60 bins. The first usable bin was centred at a depth of $20.33 \mathrm{~m}$. The five bins immediately above the bottom were eliminated because of bottom echo contamination. Bins from depths of 20 to $125 \mathrm{~m}$ were thus available for current and acoustic backscatter analysis. Profiles were collected every 3 s and were averaged over $5 \mathrm{~min}$ intervals. The $5 \mathrm{~min}$ raw backscatter data were corrected for spreading and absorption losses (Deines 1999) to produce a corrected (but not calibrated) relative volume backscattering strength $\left(S_{\mathrm{vr}}\right)$.

A second $307 \mathrm{kHz}$ ADCP (WH Sentinel, with $20^{\circ}$ tilted beams; Teledyne RD Instruments, Inc.) in a nearby streamlined underwater buoy (ADCP Buoy; Open Seas Instrumen- 
tation Inc.) was also moored near the bottom, looking up in the vicinity of the study site (Fig. 1). The ADCP was moored from 3 to 29 September 2003 and from 14 August to 9 October 2004. Average deployment depths were $112 \pm$ $1.2 \mathrm{~m}$ and $145 \pm 1.6 \mathrm{~m}$, respectively, and distances from the bottom were $13 \mathrm{~m}$ and $89 \mathrm{~m}$, respectively. The 65 bins were $2 \mathrm{~m}$ high, with the first bin centred at $4.17 \mathrm{~m}$ above the ADCP. The six bins directly below the surface were eliminated to remove surface echoes. The $S_{\mathrm{vr}}$ estimation was realized as previously, with parameters corresponding to the ADCP model type (from Deines 1999) and sound speeds and absorption coefficients estimated from CTD profiles at the beginning and end of the mooring periods. As in Tarling et al. (2002), a composite image of the $S_{\mathrm{vr}}$ over a $24 \mathrm{~h}$ period was computed for each month. We used the median as the central statistic instead of mean to minimize the influence of extreme values and asymmetric distributions. For the 3-month series of 2004, additional monthly composite images were computed for the vertical velocity, corrected for a $\sim-4 \mathrm{~mm} \cdot \mathrm{s}^{-1}$ global bias, obtained by integrating over all depths and time series and median-filtered with a $6 \mathrm{~m} \times 50 \mathrm{~min}$ kernel to filter out high-frequency variability. Such a 24 h low-pass filtered estimate of ADCP vertical velocity is interpreted as a proxy for vertical swimming speed (e.g., Tarling et al. 2002; Jiang et al. 2007). As in Jiang et al. (2007), we then imposed a condition to consider the vertical velocity estimate of each bin as valid. This condition required that a minimum of $25 \%$ of good pings were used when the ADCP firmware computed the three- or four-beam Doppler solution for the bin. Also, to compute the monthly composite, bins in which nonvalid velocity occurred more than $50 \%$ of the time were excluded. As in Jiang et al. (2007), the median $S_{\mathrm{vr}}$ in the 10$30 \mathrm{~m}$ stratum was computed for the 2004 series to trace the timings of the krill scattering layer (SL) arrival and departure from the upper water column along the 3-month period. Similarly, the ascent and descent timings were traced from the time series of the median vertical velocity of the 60$70 \mathrm{~m}$ midwater-column stratum.

The acoustic system used for biomass estimations was a Simrad EK60 scientific echosounder (Kongsberg Maritime AS, Horton, Norway), with two hull-mounted split-beam transducers operating at $120 \mathrm{kHz}\left(3^{\circ}\right)$ and $38 \mathrm{kHz}\left(7^{\circ}\right)$. The ping repetition rate was $1 \cdot \mathrm{s}^{-1}$, which corresponds to a horizontal distance of $1.29 \mathrm{~m}$ at a Bioness ${ }^{\mathrm{TM}}$ sampling speed of 2.5 knots. The upper $12 \mathrm{~m}$ (range $7 \mathrm{~m}$ ) of the water column were ignored because of necessary initial blanking and contamination by ringing. The acoustic system was calibrated with the standard sphere method for each frequency (Foote et al. 1987). The Simrad EK60 raw data were converted to HAC standard format via ER60 and analysed with the $\mathrm{CH} 2$ echo-integration and editing software (Simard et al. 2000). Volume backscattering data exceeding the estimated noise level profiles were kept for echo-integration at 38 and $120 \mathrm{kHz}$. Three echo-integrations were performed (volume backscattering index metric, $s_{\mathrm{v}}$, in $\mathrm{m}^{2} \cdot \mathrm{m}^{-3}$; Simmonds and MacLennan 2005). The first one was done with the $120 \mathrm{kHz}$ data using $2 \mathrm{~m}$ vertical $\times 10 \mathrm{~s}$ (10 pings) bins for a comparison with Bioness ${ }^{\mathrm{TM}}$ zooplankton samples. The second and third echo-integrations were made with the 120 and $38 \mathrm{kHz}$ data using a resolution similar to the onboard ADCP $S_{\mathrm{vr}}$ bins $(5 \mathrm{~m} \times 5 \mathrm{~min})$. Contaminations from ADCP transmissions, whales swimming through the acoustic beam, and occasional wrong pings due to bubble clouds near the transducer were excluded from the data. Copepods did not significantly contribute to the backscatter strength because of their relatively low densities (maximum 50 individuals $\cdot \mathrm{m}^{-3}$ during the first $52 \mathrm{~h})$ and low mean target strength $\mathrm{TS}_{\mathrm{N}}(\sim-103 \mathrm{~dB}$ for a $2-$ $3 \mathrm{~mm}$ copepod at $120 \mathrm{kHz}$ (Stanton and Chu 2000; Mair et al. 2005)), which would give volume backscattering strengths $\left(S_{\mathrm{v}, 120}=10 \log \left(s_{\mathrm{v}}\right)=\mathrm{TS}_{\mathrm{N}}+10 \log \left(\right.\right.$ individuals $\left.\left.\cdot \mathrm{m}^{-3}\right)\right)$ smaller than $-86 \mathrm{~dB}$ re $1 \cdot \mathrm{m}^{-1}$. Similarly, the contribution of the hyperiid amphipod $T$. libellula to the $S_{\mathrm{v}}$ was negligible because of their very low mean densities $\left(0.13\right.$ individuals $\left.\cdot \mathrm{m}^{-3}\right)$ relative to euphausiids.

Conversion of $S_{\mathrm{v}}$ to biomass was identical to that presented by Simard and Lavoie (1999) and Cotté and Simard (2005). From the size distribution of the krill sampled, a conversion factor $\overline{\mathrm{TS}}_{\mathrm{w}}$ of $-69.13 \mathrm{~dB} \cdot \mathrm{g}^{-1}$ was computed, which is identical to the value of $-69 \mathrm{~dB} \cdot \mathrm{g}^{-1}$ computed for other surveys in this area by these authors owing to the stability of the krill size distribution. A conversion factor of $-69 \mathrm{~dB} \cdot \mathrm{g}^{-1}$ was thus applied for our conversion to get biomass per cubic metre $(B)$ :

$$
B=s_{\mathrm{v}} / 10^{\left(\overline{\mathrm{TS}}_{w} / 10\right)}
$$

\section{Results}

\section{Physical conditions}

A thermocline oscillating around $10-20 \mathrm{~m}$ separated the surface $(0-20 \mathrm{~m})$ and subsurface $(20-40 \mathrm{~m})$ waters (salinities, 29-30 and 30-31.5 PSU, respectively; temperatures, $>4$ and $1.5-4{ }^{\circ} \mathrm{C}$, respectively) (Fig. 2). Underneath, a cold $\left(-0.5\right.$ to $\left.1.5{ }^{\circ} \mathrm{C}\right)$ intermediate layer (CIL), between 40 and $100 \mathrm{~m}$ depths, overlaid the Atlantic waters with salinities $>33$ PSU and temperatures $>1.5^{\circ} \mathrm{C}$, which were more prominent around high water. Horizontal velocities from the onboard ADCP were strongly tidally modulated, with strongly barotropic along-channel flood currents towards the head of the channel and the inverse during ebb, albeit less barotropic with increased shears near the pycnocline, the reversals lagging the tidal amplitude by about $1-3 \mathrm{~h}$ (Fig. $3 a$ ). Crosschannel currents were much weaker and more baroclinic, characterized by northward flow in upper water column around high water (Fig. 3b). Tidal streams were evident in the upper layers $(<40 \mathrm{~m})$, with north coast headings for a few hours after low water and the inverse thereafter. Below $50 \mathrm{~m}$, the currents were more variable and the tidal imprint was less apparent.

\section{Krill distribution}

DVM of M. norvegica and T. raschi were evident from the stratified Bioness ${ }^{\mathrm{TM}}$ samples (Fig. 4). During daytime, all krill was below $40 \mathrm{~m}$, within the CIL and the deep layer. During the first two nights (4 to 6 September), between 1900 and $0500,60 \%$ to $80 \%$ of the euphausiid population was above $40 \mathrm{~m}$, which leaves a significant part of the population below $40 \mathrm{~m}$. On 5-6 September, for $3 \mathrm{~h}$ around midnight, the $M$. norvegica population largely left the surface layer $(0$ $20 \mathrm{~m}$; Fig. 4a). On the last night, the relative zooplankton (krill and copepods) concentration in the upper layers was higher. This apparent change in vertical distribution was as- 
Fig. 2. (a) Tide level from the Canadian tide and currents tables and (b) density, $(c)$ temperature, and $(d)$ salinity measured by the Bioness $^{\mathrm{TM}}$ during the sampling. Bold lines in $(c)$ and $(d)$ separate the four layers. Hatched area corresponds to missing data, and white dotted lines correspond to Bioness ${ }^{\mathrm{TM}}$ profiles. Note: through the paper, time is expressed using the 24-hour system; in the figures, however, the numbers have been truncated for readability, for example, 1200 is expressed simply as 12.
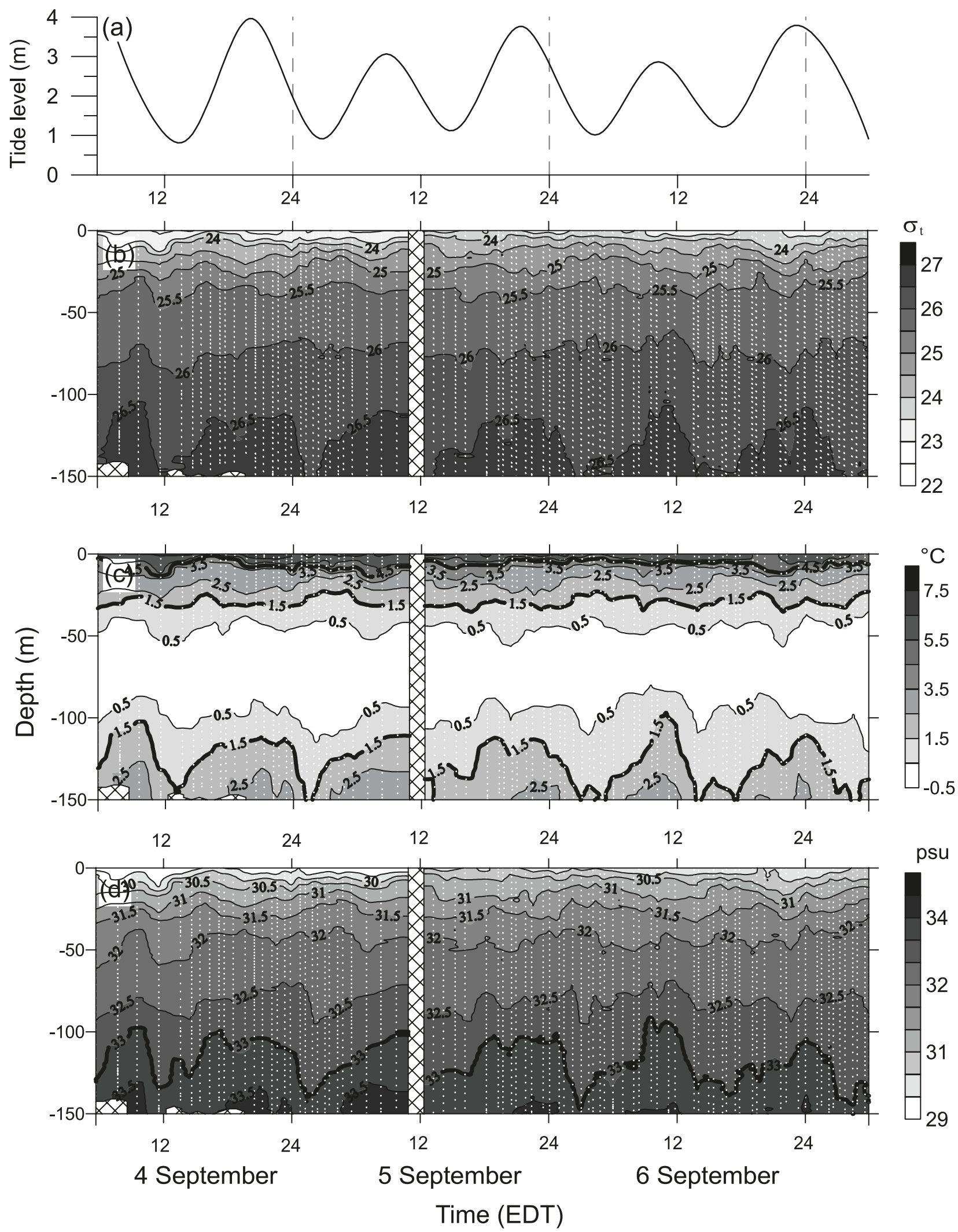
Fig. 3. Measurements from the onboard $153 \mathrm{kHz}$ acoustic Doppler current profiler (ADCP) from 5 (at 1817) to 7 (at 0602 ) September 2003. (a) Along-channel and (b) cross-channel current velocities. Negative values are oriented toward the head of the channel and to the north shore. $(c)$ Uncalibrated relative volume backscattering strength $\left(S_{\mathrm{vr}}\right.$ rel dB). See Fig. 2 caption for note regarding expression of time.

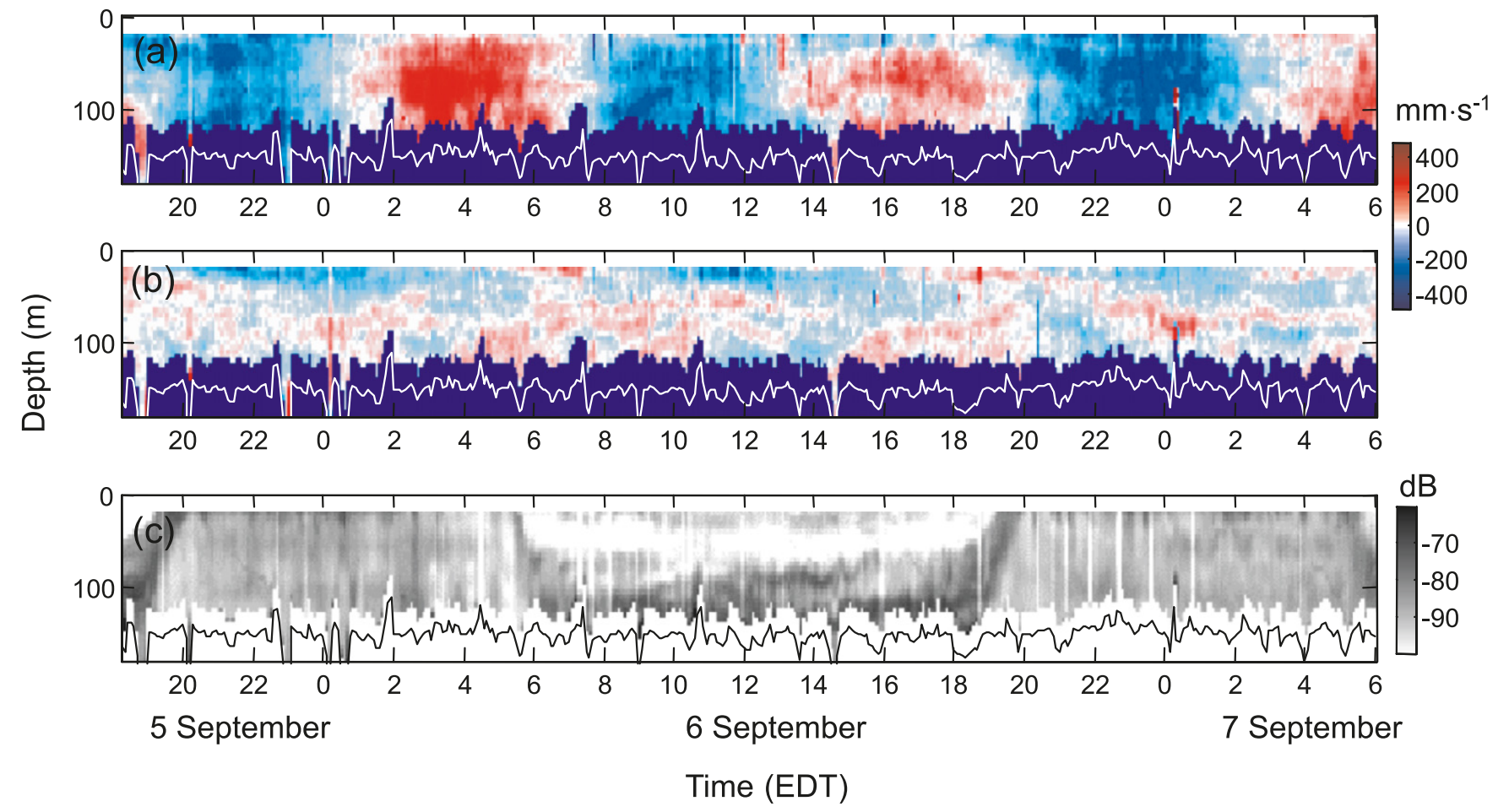

sociated with an increase by a factor 5 of the zooplankton abundance inferred from the Bioness ${ }^{\mathrm{TM}}$ and integrated over the entire water column. From 2100 on 3 September to the end of the sampling period, the maximal concentrations of $M$. norvegica and $T$. raschi inferred from the Bioness ${ }^{\mathrm{TM}}$ in the surface layer changed, respectively, from 5 and 20 individuals $\cdot \mathrm{m}^{-3}$ to 50 and 80 individuals $\cdot \mathrm{m}^{-3}$.

\section{Acoustic data}

The $S_{\mathrm{v}}$ at $120 \mathrm{kHz}$ was mainly due to euphausiids (Figs. 4 and $5 b$ ). The log-log regressions of the acoustic estimates of krill biomass against Bioness ${ }^{\mathrm{TM}}$ catches were significant $\left(r^{2}>0.24, p<0.05\right)$ for both daytime and nighttime, with slopes of 1.88 and 0.85 , respectively. The highest krill concentration estimated from the $S_{\mathrm{v}, 120}$ occurred during daytime, between 100 and $150 \mathrm{~m}$, whereas the net catches were highest during the night. The $S_{\mathrm{v}, 120}$ reached $-60 \mathrm{~dB}$ re $1 \mathrm{~m}^{-1}$, which corresponds to 50 euphausiids $\cdot \mathrm{m}^{-3}$ or $14 \mathrm{~g} \cdot \mathrm{m}^{-3}$. A weak SL $\left(S_{\mathrm{v}, 38}=-80 \mathrm{~dB}\right.$; Fig. $\left.5 a\right)$ in the surface layers in daytime (between 0700 and 1800) was classed as small fish by the $S_{\mathrm{v}}$ difference between the two frequencies $\left(S_{\mathrm{v}, 120-38}\right.$ near $2 \mathrm{~dB}$; Fig. $5 c$ for significant backscatter, where $S_{\mathrm{v}, 120}>$ $-90 \mathrm{~dB}$ and $S_{\mathrm{v}, 38}>-95 \mathrm{~dB}$ ). Several single fish tracks were clearly visible on the echogram when the ship was not moving. These tracks were good candidates to measure the in situ $\mathrm{TS}_{N, 120}$ of these fishes from the split beam analyses, which revealed to be $\sim-60 \mathrm{~dB}$. During nighttime, small individual targets with $\mathrm{TS}_{N, 120}$ between -50 and $-70 \mathrm{~dB}$ emerged from the bottom. They were likely fish (probably small demersal fish and capelin) and northern shrimp (Pandalus borealis) that were caught by the Bioness ${ }^{\mathrm{TM}}$ (one to five organisms per sample) in the bottom layer and corresponded to a $S_{\mathrm{v}, 120}-S_{\mathrm{v}, 38}$ difference of $\sim 2 \mathrm{~dB}$ (Fig. $5 c$ ).

The ascent of the krill SL to the surface layers started at 1800, which corresponded to sunset, and the organisms reached the surface in $1 \mathrm{~h}$. The descent at dawn was well defined on 7 September and took place between 0500 and 0600 (Fig. 3c), which corresponded to sunrise. On 6 September, however, the descent was less sharp, which was also noted on the ADCP $S_{\mathrm{vr}}$ and stratified net samples (Figs. $4 a-$ $4 b)$. A substantial part of the euphausiid population had migrated downwards well before sunrise. Soon after the ascent, a weak SL reappeared between 100 and $130 \mathrm{~m}$, and significant $S_{\mathrm{v}}$ was present at intermediate depths during the night (Fig. $5 b$ ).

\section{Chlorophyll distribution and krill stomach content}

The chlorophyll $a$ concentration from the Bioness ${ }^{\mathrm{TM}}$ in situ fluorometer showed high values in the upper $20 \mathrm{~m} \mathrm{(2-}$ $15 \mathrm{mg} \cdot \mathrm{m}^{-3}$ ) (Fig. 6a). The concentration was highest at the surface and rapidly decreased to near 0 at 25-30 m. Chlorophyll $a$ extracted from water samples gave the same general pattern (Fig. 6b). The average chlorophyll $a$ concentration in the surface layer steadily increased over the three days. The highest concentrations $\left(>12 \mathrm{mg} \cdot \mathrm{m}^{-3}\right)$ were observed on the last day at the same time that the zooplankton concentration increased.

The average chlorophyll $a$ stomach contents of $M$. norvegica and $T$. raschi over all layers increased during the night (Figs. $6 c-6 d$ ). One hour after the ascent, the chlorophyll $a$ concentration in the krill stomachs sampled below $100 \mathrm{~m}$ was as high as for those sampled in the surface layers. In 
Fig. 4. (a) Meganyctiphanes norvegica and (b) Thysanoessa raschi vertical distribution (\%) observed from 4 to 7 September 2003 by the net sampling. Dashes represent Bioness ${ }^{\mathrm{TM}}$ samples and hatched areas correspond to the lack of organisms over all the vertical profile. Day and night are indicated above each plot by open and solid horizontal bars, respectively. See Fig. 2 caption for note regarding expression of time.

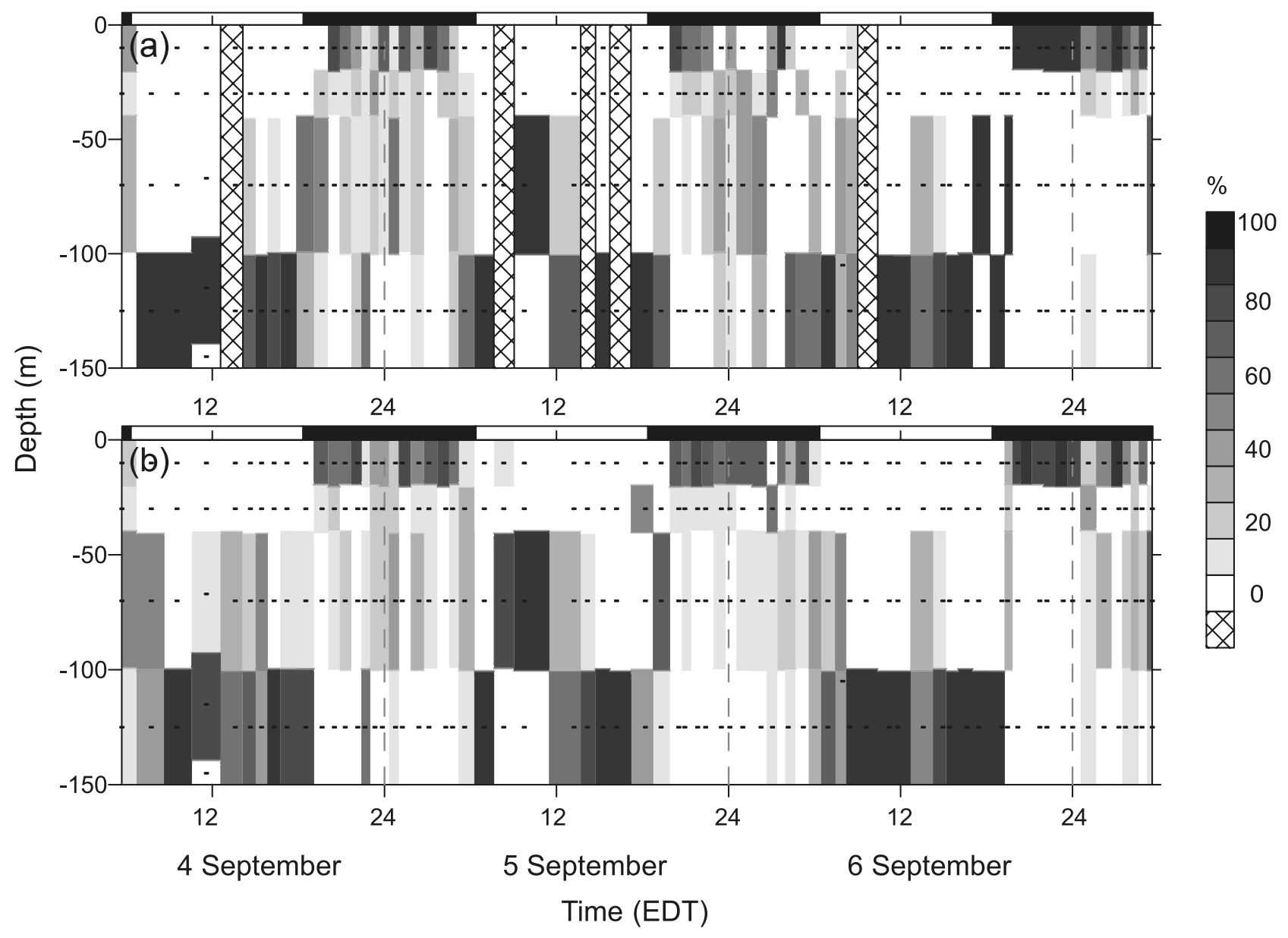

daytime, the chlorophyll $a$ in the stomachs decreased exponentially with time. For $M$. norvegica, the fluorescence signal reached its background value at 1200 (around 10 ng.individual ${ }^{-1}$ ), several hours after the dawn descent. For T. raschi, the background signal was lower than the measurable concentration, and the daytime concentrations were arbitrarily set to zero. A trend to higher average chlorophyll $a$ content was observed over the three days for both species and was associated with the increase of the average chlorophyll concentration in surface waters. The maximum chlorophyll $a$ stomach concentration increased by one order of magnitude between the first and third day, changing from 100 to $>1000 \mathrm{ng} \cdot$ individual $^{-1}$ for $M$. norvegica and from 7 to $>65 \mathrm{ng} \cdot$ individual $^{-1}$ for $T$. raschi. Meganyctiphanes norvegica stomach pigment content tended to increase during night. For example, the chlorophyll $a$ concentration in stomach changed from 10 to $100 \mathrm{ng} \cdot$ individual $^{-1}$ from 2000 to 0600 during the first night.

\section{Acoustic data from moored ADCP}

The high-resolution stratified Bioness ${ }^{\mathrm{TM}}$ samples confirmed that krill was the main component of the highfrequency sound backscattering observed by the vessel- mounted ADCP and EK60 echosounder. During September 2003, the ascent and descent clearly showed up at $\sim 1900$ and 0530 on the composite $24 \mathrm{~h} S_{\mathrm{vr}}$ echogram of the moored ADCP (Fig. 7a) in accordance with sunset and sunrise and vessel survey (Figs. $3 c$ and $5 b$ ). The series of similar echograms for August to October 2004 clearly evidenced the photoperiod effect on the DVM (Figs. $7 b, 7 d$, and $7 f$ ). From August to October, the ascent advanced from 2000 to 1800 and the descent was delayed from 0530 to 0630 . This lengthening of DVM nocturnal phase almost perfectly matched the lengthening of the night (Fig. 8a). The arrival in the surface layer was $\sim 30-60$ min after sunset and departure was $\sim 15-0 \mathrm{~min}$ before sunrise. As with ship-based $S_{\mathrm{v}}$, the $S_{\mathrm{vr}}$ below $80 \mathrm{~m}$ on all monthly composite echograms was minimal during the $2 \mathrm{~h}$ window following the dusk ascent in which all the krill SL took part (Figs. $7 a, 7 b, 7 d, 7 f$ ). Soon after the ascent, some krill started to redistribute over the whole water column and the deep SL started to reform, giving rise to a bimodal nocturnal vertical distribution. During some nights, clear descent trajectories were evident on the $S_{\mathrm{vr}}$ high-resolution time series (not shown). $S_{\mathrm{vr}}$ at intermediate depths was often significant, especially around midnight (e.g., Fig. 7b). The dense SL in surface layers also tended to 
Fig. 5. Volume backscattering strength $\left(S_{\mathrm{v}}, \mathrm{dB}\right.$ re $\left.1 \mathrm{~m}^{-1}\right)$ from 5 to 7 September 2003 at $(a) 38$ and $(b) 120 \mathrm{kHz}$ from the Simrad EK60 echosounder. Vertical and horizontal resolutions are $2 \mathrm{~m}$ and $5 \mathrm{~min}$, respectively. (c) The $S_{\mathrm{v}}$ difference at the two frequencies $\left(S_{\mathrm{v}, 120}-S_{\mathrm{v}, 38}\right)$ was calculated to classify the echoes except for blanked areas with insignificant backscatter and low signal to noise ratios $\left(S_{\mathrm{v}, 38}<-95 \mathrm{~dB}\right.$ and $\left.S_{\mathrm{v}, 120}<-90 \mathrm{~dB}\right)$. SS, sunset; SR, sunrise. See Fig. 2 caption for note regarding expression of time.

SS

SR

SS

SR
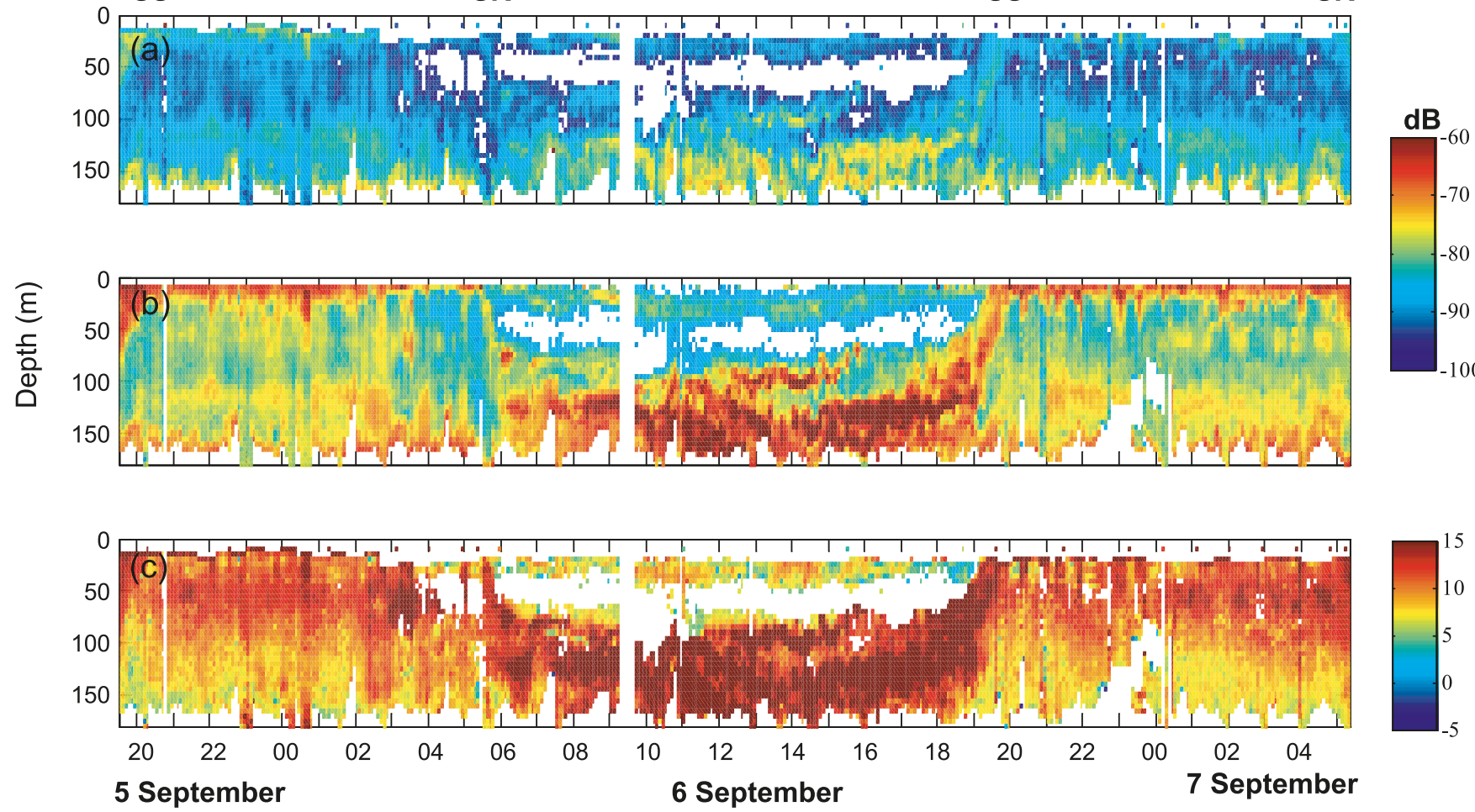

Time (EDT)

thicken around midnight but concentrated again in a thinner layer before dawn. The composite $S_{\mathrm{vr}}$ echograms show that the deeper daytime depth was reached a couple of hours after the bulk descent. A mirror pattern is shown before the ascent. However, the high-resolution $S_{\mathrm{vr}}$ series showed a substantial amount of small-scale variability around this general trend for both day and night patterns over the water column, likely partly in response to krill small- and mesoscale patchiness and advection. The monthly composites of low-pass filtered vertical velocity (Figs. 7c, 7e, 7g) evidenced the bulk ascent and descent at sunset and sunrise and the substantial nocturnal descent starting just after the ascent and extending until about midnight. The ADCP data indicated a trend to increased swimming speed along the ascent (e.g., Fig. 7c).

A weaker vertically migrating SL was observed in the surface layer during daytime on the ADCP time series (Figs. $7 a, 7 b, 7 d, 7 f$ ). Examination of the $S_{\mathrm{vr}}$ on the four beams of the ADCP separately indicated that this SL was not homogeneous, which is indicative of more patchy distributions of scatterers, likely fish aggregates (Jiang et al. 2007). This SL was similar to the fish SL (likely capelins according to Bioness ${ }^{\mathrm{TM}}$ catches) observed by the ship echosounder in the surface layer during the day (Figs. 5b, $5 c$ ). These organisms had another light intensity preferendum. Like krill, they avoided the surface layer during daytime but formed a loose SL around $30 \mathrm{~m}$ depth.

\section{Discussion}

Despite a little contamination by other sparse species, possible masking effects of 3D krill patchiness and shearing advection, the acoustic data from both the ADCPs and the EK60 echosounder clearly showed strong krill DVM with fine resolution details. Stratified sampling with the Bioness ${ }^{\mathrm{TM}}$ corroborated the SL composition, with a $S_{\mathrm{v}, 120}-S_{\mathrm{v}, 38}$ signature of 10 to $2 \mathrm{~dB}$, typical of local krill during daytime (Simard and Lavoie 1999). Both direct sampling and acoustic data sets exhibited significant variability resulting in low global correlation between the acoustic and direct sampling, likely largely due to 3D misalignment of both types of samples, their differing sampling volumes, krill patchiness, and the relative diel catchability and bias of the two gears as revealed by the differing $S_{\mathrm{v}, 120}$ versus krill catch slopes during daytime and nighttime (Miyashita et al. 1996; Wiebe et al. 2004; Chu and Wiebe 2005). Examining this sampling gear performance is out of the scope of this paper and will be discussed elsewhere.

\section{DVM dynamic pattern}

The average krill DVM pattern during our sampling period appears to be as follows. In daytime, krill was concentrated in a dense SL below $\sim 90 \mathrm{~m}$. A few hours before sunset, individuals near the upper boundary of the SL slowly began to migrate upwards. This motion accelerated at sunset, when essentially all the SL joined these early migrants, 
Fig. 6. Chlorophyll $a(\mathrm{Chl} a)$ vertical distribution $\left(\mathrm{mg} \cdot \mathrm{m}^{-3}\right)$ estimated by $(a)$ the Bioness ${ }^{\mathrm{TM}}$ in situ fluorometer and $(b)$ water samples from 4 to 7 September 2003. Chl $a$ stomach contents (ng Chl $a$-individual ${ }^{-1}$ ) for (c) Meganyctiphanes norvegica and (d) Thysanoessa raschi. Dots $(a)$, arrowheads $(b)$, and dashes $\left(c\right.$ and $d$ ) indicate samples and Bioness ${ }^{\mathrm{TM}}$ profiles, and hatched areas correspond to (a) missing values or $(c$ and $d$ ) a lack of organisms. See Fig. 2 caption for note regarding expression of time.

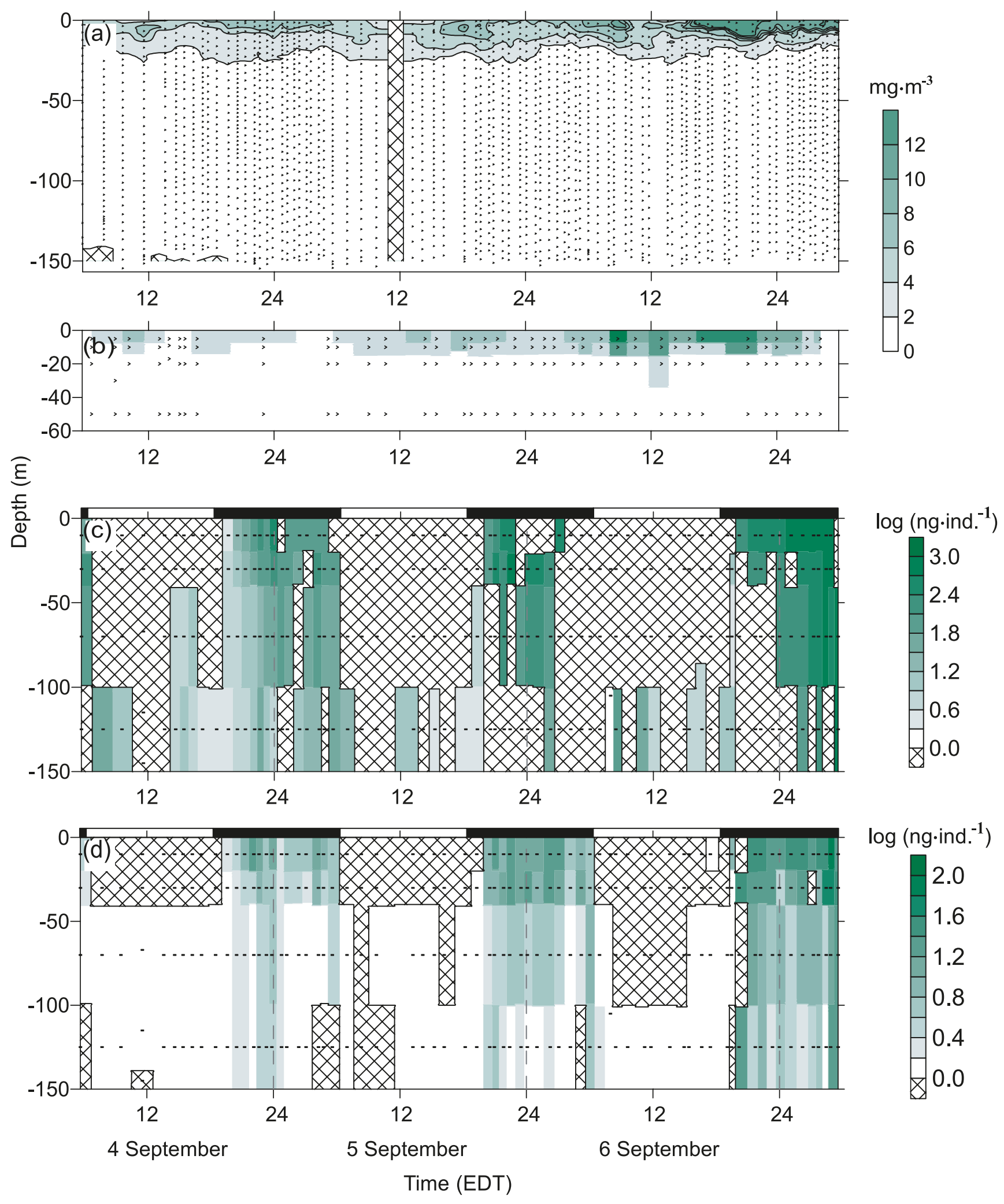


Fig. 7. Twenty-four hour composite images of uncalibrated relative volume backscattering strength median $\left(S_{\mathrm{vr}}\right.$ rel dB) from the $307 \mathrm{kHz}$ moored acoustic Doppler current profiler (ADCP) series in (a) September 2003, (b) August, (d) September, and $(f)$ October 2004, with $(c, e, g)$ corresponding low-pass filtered vertical velocity median for 2004. Blank areas correspond to nonvalid velocities. See Fig. 2 caption for note regarding expression of time.

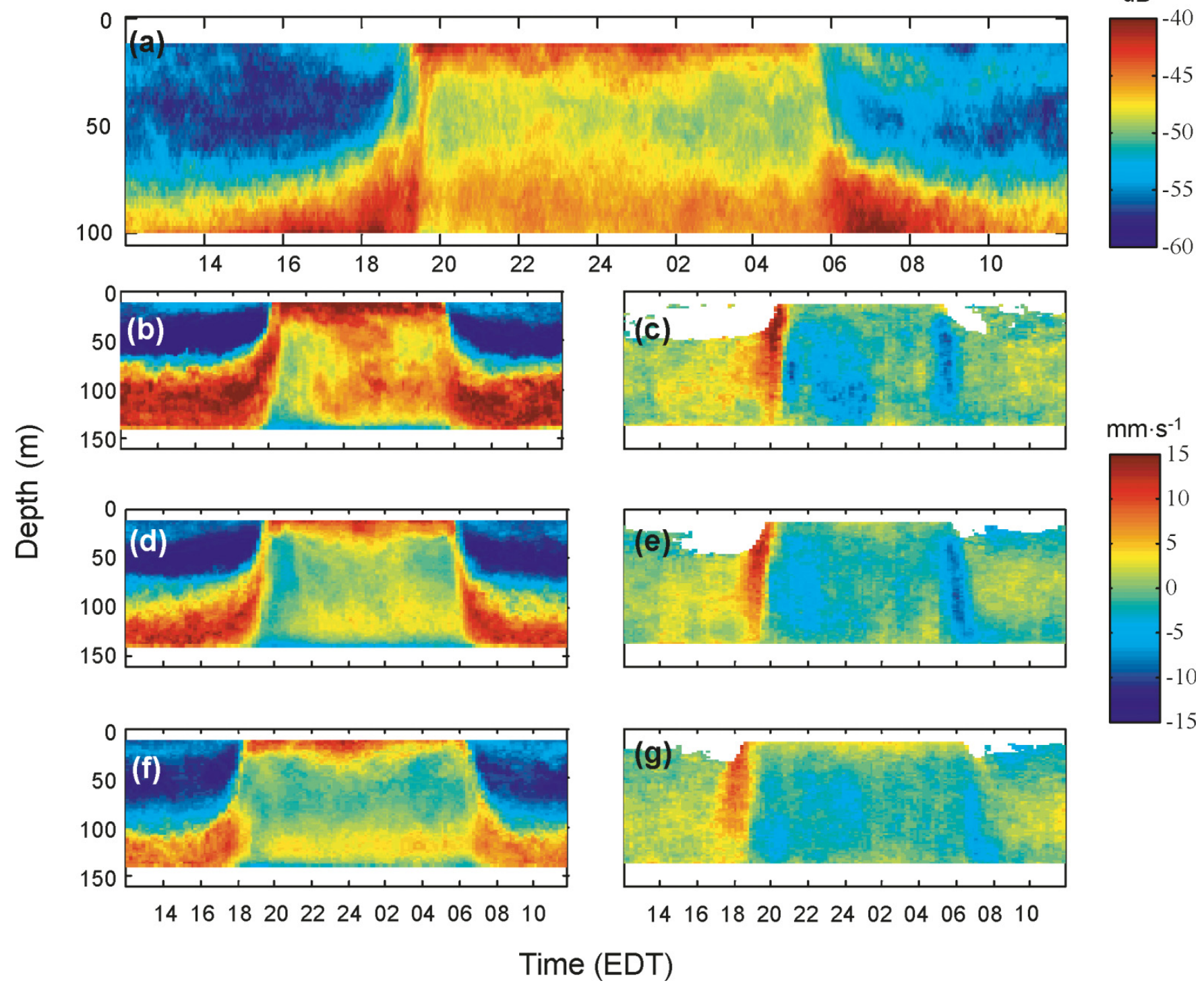

reaching the surface layer in about $1 \mathrm{~h}$ at an average vertical swimming speed of $\sim 150 \mathrm{~m} \cdot \mathrm{h}^{-1}\left(42 \mathrm{~mm} \cdot \mathrm{s}^{-1}\right)$ in agreement with results from other studies (Hardy and Bainbridge 1954; Tarling et al. 1999; Thomasson et al. 2003). Estimates of median vertical speed of the ascent from the ADCP monthly composites were about $50 \%$ lower. This bias (also noted by Heywood (1996) and Tarling et al. (2002)) is likely due to the necessary time-depth smoothing window used in processing the noisy high-resolution ADCP vertical velocities, themselves obtained by averaging over all individuals insonified in the time-depth sample bins. The observed increase in vertical swimming speed at the end of the ascent may indicate a sorting of the krill by swimming speeds in the final step when the barrier isolume controlling the ascent is no longer acting and the rate of change in light intensity is peaking (cf. Tarling et al. 2002). As soon as $1 \mathrm{~h}$ later, the newly formed surface SL starts to disperse over the water column and reform a deep SL between 90 and $130 \mathrm{~m}$. The ADCP velocity then indicates downward swimming krill over all subsurface layers, starting immediately after the SL reached the surface and extending to midnight. This downward movement appears as active swimming and not passive sinking. This is supported by the fact that the downward velocity is as fast as that of the descent, the occasional observations of synchronous nocturnal descents with slopes mirroring the ascent on the DVM pattern of the highresolution $S_{\mathrm{vr}}$ time series, the rapid formation of the SL at depth, and the stomach pigment content of its krill. The increase of stomach pigments over the night at each depth for both species tends to confirm the continuing downward movement observed by ADCP vertical velocities during a large part of the night, despite the complex dynamics of the 
Fig. 8. (a) Time series of $24 \mathrm{~h}$ periods with a $10 \mathrm{~min}$ resolution of the uncalibrated relative volume backscattering strength $\left(S_{\mathrm{vr}}\right.$ rel dB) median over the 10-30 m layer from the $307 \mathrm{kHz}$ moored acoustic Doppler current profiler (ADCP) in 2004, and (b) similar twodimensional time series for the low-pass filtered vertical velocity median in the 60-70 m layer, showing the bulk ascent and descent times. The superimposed broken lines indicate sunset and sunrise time series. See Fig. 2 caption for note regarding expression of time.

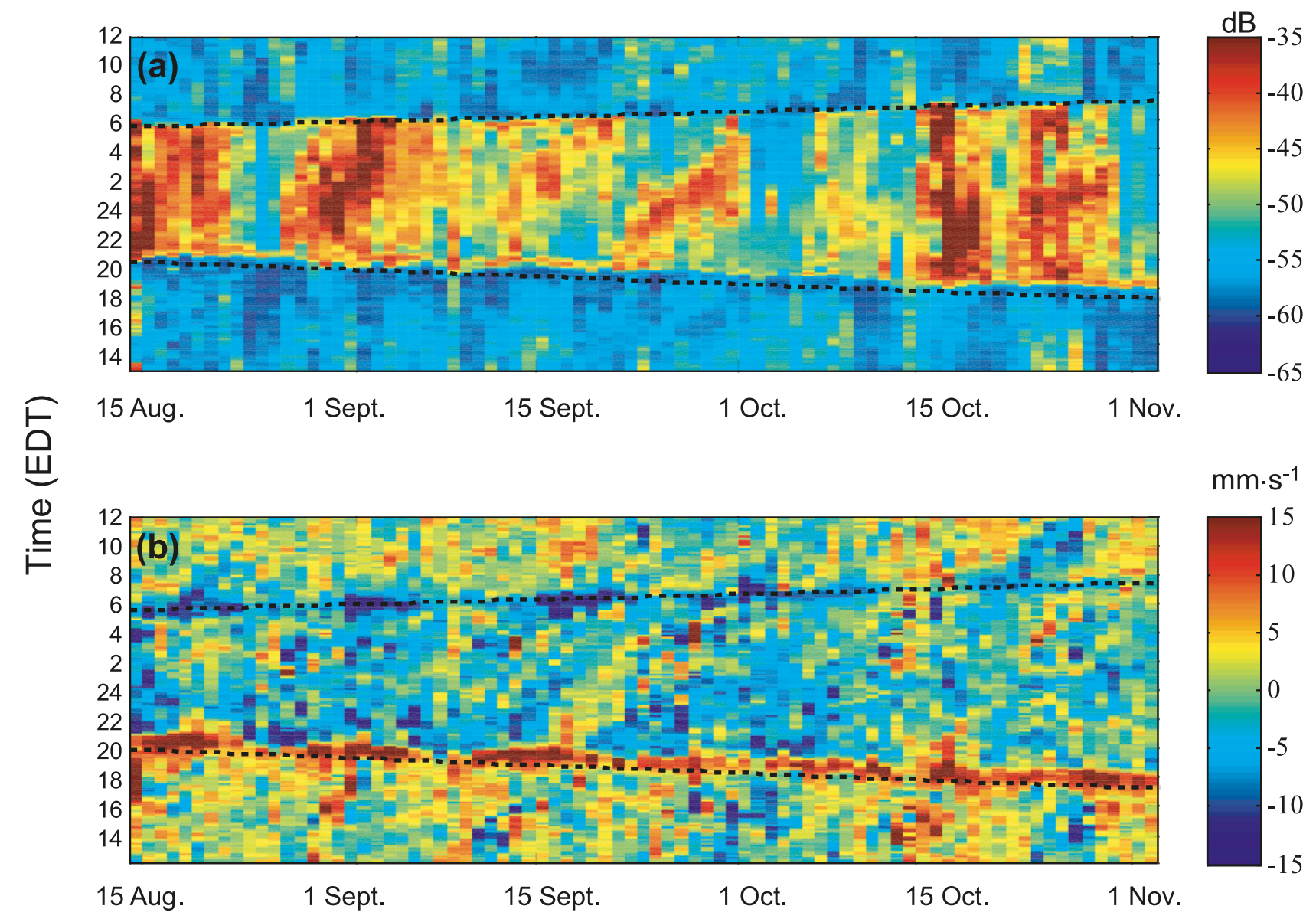

\section{Date}

in situ stomach pigments (Moloney and Gibbons 1996). Although the bimodal vertical distribution is maintained overnight on average, day-to-day variability is observed. A change in krill vertical dynamics appears to occur around midnight, as indicated by the trend to higher $S_{\mathrm{vr}}$ at intermediate depths, the end of the thickening of the dense surface SL, and the vanishing of the downward swimming speed over the water column. Is this an indication that part of the krill is initiating a second intensive feeding bout before dawn? The absence of increasing $S_{\mathrm{vr}}$ in the deep SL when downward swimming ended and nonrenewal of the stomach pigments of its main constituent for $T$. raschi all tend to support this hypothesis of a predawn meal (cf. Simard et al. 1985). This is less evident for the less abundant $M$. norvegica, though its catches and stomach pigment content on 4 and 5 September are in favour of such a possibility. The final descent is initiated by the first gleam of light some 15 min before sunrise, with a swimming speed similar to that of the ascent. The density of the descending SL is lower than that of the ascending one at dusk because a significant fraction of the krill has already returned to their daytime depth. After the bulk descent, the daytime depth tends to continue to deepen until noon before the cycle is resumed.
In summary, the average DVM pattern includes two synchronous twilight vertical movements, synchronised by changing light intensity, and asynchronous nocturnal migrations, marked by a change of dynamics at midnight likely from a change of vertical migration direction from part of the krill. Stomach content tracing and the general pattern are all supportive of the DVM hunger-satiation hypothesis (Pearre 2003a). The observed higher proportion of krill catches in the surface layer during the third night when the phytoplankton concentration was higher is not incoherent with this model, as the nocturnal vertical pattern of stomach pigments was maintained, and the formation of nocturnal deep and intermediate SLs repeated on the ship's echogram. The apparent inconsistency from net samples may result from masking due to krill patchiness and differential advection history in the vertical, which can not be ruled out from the 3D current structure.

All krill synchronously migrate to the surface at dusk to feed; satiated individuals rapidly swim back to their daytime depth and reform a deep SL while others continue to feed in surface waters. Around midnight, a larger part of the population is satiated and leaves the surface layer. Some krill rejoin the deep SL but others go back to surface to feed again be- 
fore the increasing light intensity at dawn brings them back to their daytime depth. Natural variability in krill and phytoplankton patchiness, diet (Kaartvedt et al. 2002), feeding history, and physiological state, combined with tidal and other frequency fluctuations in $3 \mathrm{D}$ circulation patterns, produce a variety of realisations of this general model. As pointed out by Pearre $(1979,2003 a, 2003 b)$, the sampling requirements to evidence this complex vertical behaviour are seldom met. Adequate DVM tracking for a single species is difficult; simultaneously tracking several members of the community at different trophic levels is much more complex (cf. Tarling et al. 2002; Pearre 2003b), and requirements in gears diversity and simultaneous sampling platforms are beyond the means of usual research. High-resolution acoustics (ADCP, multifrequency, and others) has improved our means of tracking mass movements on the vertical and, to a certain degree, the bulk vertical swimming speed of scatterers, but tracking interchanges and validating acoustics with direct sampling are still difficult and time-consuming, and controlling for masking effects of 3D patchiness and advection requires special attention.

The ADCP time series during fall provided evidence of photoperiod control on DVM timing. Further studies should extend such observations to the winter period to monitor the effect of the change of in situ light intensity by the presence of the sea ice cover, generally present between January and April in the Gulf and Estuary. As observed in arctic environments (Blachowiak-Samolyk et al. 2006; Cottier et al. 2006), the krill should adapt their behaviour to maximize their fitness, and the asynchronous component of the vertical migration within the population may become more important.

\section{Implication on mesoscale krill advection}

The effect of nocturnal asynchronous migrations and vertical distribution on krill advection into the Estuary from the Gulf was assessed by estimating the transport on the $44 \mathrm{~km}$ long cross section at the mouth of the Estuary by coupling the average DVM pattern with simulated currents from the 3D regional circulation model (for details, see Sourisseau et al. 2006). Three-year (1997 to 1999) simulated currents were averaged. Cross-sectional mean currents above $40 \mathrm{~m}$ are downstream at $150 \mathrm{~m} \cdot \mathrm{h}^{-1}$ and upstream in the CIL (40$100 \mathrm{~m}$ ) and below $(100-150 \mathrm{~m})$ at 52 and $32 \mathrm{~m} \cdot \mathrm{h}^{-1}$, respectively. Assuming no nocturnal spreading of the krill over the water column and a diel residence time of $10 \pm 2 \mathrm{~h}$ above $40 \mathrm{~m}$ and $14 \pm 2 \mathrm{~h}$ below $100 \mathrm{~m}$, krill would be flushed out of the Estuary at an average speed of about $43.8 \mathrm{~m} \cdot \mathrm{h}^{-1}$. This is in agreement with regional modeling studies of DVMtrained zooplankton (Zakardjian et al. 1999; Sourisseau et al. 2006) indicating that the average ratio of time spent in the deep layers $(100-150 \mathrm{~m})$ relative to surface layers $(0-40 \mathrm{~m})$ must be higher than five (20/4) to maintain zooplankton in the Estuary.

Assuming that $30 \%$ of the population is spread over the water column during the night, starting $2 \mathrm{~h}$ after the ascent, the average time spent in September in the surface layers, the CIL, and the deep layer are now 7, 3, and $14 \mathrm{~h} \cdot \mathrm{day}^{-1}$, respectively. Even with such DVM behaviour, the individuals are flushed out of the Estuary by the laterally averaged currents at the cross section at mouth of the Estuary, but at a slower speed $\left(18.2 \mathrm{~m} \cdot \mathrm{h}^{-1}\right)$. The exact fraction of the popula- tion below $40 \mathrm{~m}$ during the night was not accurately evaluated acoustically because acoustic information in the first metres (0-12 m) was lacking and the average krill tilt-angle profile during night was unknown. The $30 \%$ gross estimate comes from the Bioness ${ }^{\mathrm{TM}}$ samples, which also contain a level of uncertainty due to diel change in krill catchability as evidenced by the day-night $S_{\mathrm{v}}$ vs. catch regressions.

Previous results from a 3D modeling study (Sourisseau et al. 2006) concluded that krill import on the cross section must occur mainly on the north side of the Estuary. Cross-sectional mean current profiles were computed for the first $15 \mathrm{~km}$ segment from the north shore. The currents in the 0-40 m layer are then downstream at a speed of $97 \mathrm{~m} \cdot \mathrm{h}^{-1}$ and upstream at -77 and $-49 \mathrm{~m} \cdot \mathrm{h}^{-1}$ in the $40-100$ and $100-150 \mathrm{~m}$ layers, respectively. The krill advection using the above average DVM model is now upstream at an average speed of $10 \mathrm{~m} \cdot \mathrm{h}^{-1}$. These new estimates show that the observed average DVM model incorporating nocturnal vertical spreading of a fraction of the krill is insufficient to explain the observed persistent retention of the krill in the Estuary and the resulting dense mesoscale aggregation at the head of the deep Laurentian Channel in the Saguenay - St. Lawrence Marine Park (Simard and Lavoie 1999). The 3D current structure in the Estuary must be an essential component for advecting and importing krill into the Estuary from the sourcing Gulf.

The following processes appear necessary to explain the krill recruitment and aggregation at the head of the Laurentian Channel in the St. Lawrence Estuary. In agreement with Runge and Simard (1990), the first one is the flow of the CIL and the deep layer towards the head of the channel, but as expected by Simard et al. (1986a), the cyclonic structure of circulation within the Estuary, with an inflowing current along the north shore and an outflowing coastal jet flushing the Estuary on the south shore, is an intrinsic part of the process that must be carefully taken into account. Crosschannel-averaged currents or coarse grid modeling can not reproduce the actual krill aggregation, as Sourisseau et al. (2006) clearly demonstrated recently, and the krill import may occur mainly in a thin filament along the northern slope of the Laurentian Channel. This process is enhanced by the presence of wind-driven upwelling and Ekman transport on the north side, reinforcing the slope concentrating process (e.g., Cotté and Simard 2005). The second controlling component is the krill DVM pattern, the persistent nocturnal spreading of a substantial fraction of the population over the inflowing CIL, and the DVM seasonal structure. The above findings emphasize the importance of monitoring the circulation at the mouth of the Estuary and wind-generated upwelling on the north shore in an effort to provide good proxies for predicting krill biomass supply to the Estuary and the Marine Park aggregation. They also point out the need to improve our knowledge of the seasonal component of krill DVM behaviour, particularly for the period of sea ice cover. This information should help us to understand the ecological system upon which mammal populations exploiting this resource rely. It should also contribute to base management and protection decisions on sound scientific knowledge, in particular for the Saguenay - St. Lawrence Marine Park at the head of the lower St. Lawrence Estuary and the adjacent areas that are being considered for the establishment of a marine protected area. 


\section{Acknowledgements}

This work was funded by Fisheries and Oceans Canada. We thank C. Cotté and G. Caron for their help in processing zooplankton samples and data analysis. We are indebted to the crew members of the R/V Coriolis II, who were always helpful during daytime and nighttime sampling, and also to E. Doussantousse, C. Bédard, J. Pommier, E. Poirier, and C. Desjardins, who greatly participated to the field sampling. Comments from two anonymous referees were appreciated and helpful in improving the final version of this paper.

\section{References}

Arar, E.J., and Collins, G.B. 1997. Method 445.0, in vitro determination of chlorophyll $a$ and pheophytin $a$ in marine and freshwater algae by fluorescence. In Methods for the determination of chemical substances in marine and estuarine environmental matrices. National Exposure Research Laboratory, Office of Research and development, US Environmental Protection Agency, Cincinnati, Ohio. EPA/600/R-97/072.

Blachowiak-Samolyk, K., Kwasniewski, S., Richardson, K., Dmoch, K., Hansen, E., Hop, H., Falk-Petersen, S., and Mouritsen, L.T. 2006. Arctic zooplankton do not perform diel vertical migration (DVM) during periods of midnight sun. Mar. Ecol. Prog. Ser. 308: 101-116.

Boden, B.P., and Kampa, E.M. 1967. The influence of natural light on the vertical migrations of an animal community in the sea. Symp. Zool. Soc. Lond. 19: 15-26.

Chu, D., and Wiebe, P.H. 2005. Measurements of sound-speed and density contrasts of zooplankton in Antarctic waters. ICES J. Mar. Sci. 62: 818-831.

Cotté, C., and Simard, Y. 2005. Formation of dense krill patches under tidal forcing at whale feeding hot spots in the St. Lawrence Estuary. Mar. Ecol. Prog. Ser. 288: 199-210.

Cottier, F.R., Tarling, G.A., Wold, A., and Falk-Petersen, S. 2006. Unsynchronized and synchronized vertical migration of zooplankton in a high arctic fjord. Limnol. Oceanogr. 51: 2586-2599.

Deines, K.L. 1999. Backscatter estimation using broadband acoustic Doppler current profilers. In IEEE Sixth Working Conference on Current Measurements, San Diego, Calif., 11-13 March 1997. IEEE, Piscataway, N.J. pp. 249-253.

Foote, G.K., Knudsen, H.P., Vestnes, G., MacLennan, D.N., and Simmonds, E.J. 1987. Calibration of acoustic instruments for fish density estimation: a pratical guide. ICES Coop. Res. Rep. No. 144.

Genin, A. 2004. Bio-physical coupling in the formation of zooplankton and fish aggregations over abrupt topographies. J. Mar. Sys. 50: 3-20.

Genin, A., Greene, C., Haury, L., Wiebe, P., Gal, G., Kaartvedt, S., Meir, E., Fey, C., and Dawson, J. 1994. Zooplankton patch dynamics: daily gap formation over abrupt topography. Deep-Sea Res. I, 41: 941-951.

Hardy, A.C., and Bainbridge, R. 1954. Experimental observations on the vertical migrations of plankton animals. J. Mar. Biol. Assoc. U.K. 33: 409-448.

Heywood, K.J. 1996. Diel vertical migration of zooplankton in Northwest Atlantic. J. Plankton Res. 18: 163-184.

Jiang, S., Dickey, T.D., Steinberg, D.K., and Madin, L.P. 2007. Temporal variability of zooplankton biomass from ADCP backscatter time series data at the Bermuda testbed mooring site. Deep-Sea. Res. I, 54: 608-636.
Kaartvedt, S., Melle, W., Knutsen, T., and Skjoldal, H.R. 1996. Vertical distribution of fish and krill beneath water of varying optical properties. Mar. Ecol. Prog. Ser. 136: 51-58.

Kaartvedt, S., Larsen, T., Hjelmseth, K., and Onsrud, M.S.R. 2002. Is the omnivorous krill Meganyctiphanes norvegica primarily a selectively feeding carnivore? Mar. Ecol. Prog. Ser. 228: 192-204.

Kimmerer, W.J., and McKinnon, A.D. 1987. Zooplankton in a marine bay. 2. Vertical migration to maintain horizontal distributions. Mar. Ecol. Prog. Ser. 41: 53-60.

Lavoie, D., Simard, Y., and Saucier, F.J. 2000. Aggregation and dispersion of krill at channel heads and shelf edges: the dynamics in the Saguenay - St. Lawrence Marine Park. Can. J. Fish. Aquat. Sci. 57: 1853-1869.

Mackas, D.L., Kieser, R., Saunders, M., Yelland, D.R., Brown, R.M., and Moore, D.F. 1997. Aggregation of euphausiids and Pacific hake (Merluccius productus) along the outer continental shelf off Vancouver Island. Can. J. Fish. Aquat. Sci. 54: 2080-2096.

Mair, A.M., Fernandes, P.G., Lebourges-Dhaussy, A., and Brierley, A.S. 2005. An investigation into the zooplankton composition of a prominent $38-\mathrm{kHz}$ scattering layer in the North Sea. J. Plank. Res. 27: 623-633.

Miyashita, K., Aoki, I., and Inagaki, T. 1996. Swimming behaviour and target strength of isada krill (Euphausia pacifica). ICES J. Mar. Sci. 53: 303-308.

Moloney, C.L., and Gibbons, M.J. 1996. Sampling and analysis of gut contents in relation to environmental variability and diel vertical migration by herbivorous zooplankton. J. Plankton Res. 18: $1535-1556$.

Onsrud, M.S.R., and Kaartvedt, S. 1998. Diel vertical migration of the krill Meganyctiphanes norvegica in relation to physical environment, food and predators. Mar. Ecol. Prog. Ser. 171: 209-219.

Pearre, S. 1979. Problems of detection and interpretation of vertical migration, J. Plankton Res. 1: 29-44.

Pearre, S. 2003a. Eat and run? The hunger/satiation hypothesis in vertical migration: history, evidence and consequences. Biol. Rev. 78: 1-79.

Pearre, S. 2003b. When lights are low: comment on 'Midnight sinking behaviour in Calanus finmarchicus: a response to satiation or krill predation?' by Tarling et al. (2002). Mar. Ecol. Prog. Ser. 252: 303-305.

Price, H.J. 1989. Swimming behaviour of krill in response to algal patches: a mesocosm study. Limnol. Oceanogr. 34: 649-659.

Roman, M., Zhang, X., McGilliard, C., and Boicourt, W. 2005. Seasonal and annual variability in the spatial patterns of plankton biomass in Chesapeake Bay. Limnol. Oceanogr. 50: 480-492.

Runge, J.A., and Simard, Y. 1990. Zooplankton of the St. Lawrence Estuary: the imprint of physical processes on its composition and distribution. In Oceanography of a large-scale estuarine system: the St Lawrence. Edited by M.I. El-Sabh and N. Silverberg. Springer-Verlag, Berlin. pp. 297-320.

Sameoto, D.D. 1980. Zooplankton and micronekton abundance in acoustic scattering layers on the Nova Scotian slope. Can. J. Fish. Aquat. Sci. 39: 760-777.

Saucier, F.J., Roy, F., Gilbert, D., Pellerin, P., and Ritchie, H. 2003. Modeling the formation and circulation processes of water masses and sea ice in the Gulf of St. Lawrence, Canada. J. Geophys. Res. 108: 3269 .

Simard, Y., and Lavoie, D. 1999. The rich krill aggregation of the Saguenay - St. Lawrence Marine Park: hydroacoustic and geostatistical biomass estimates, structure, variability, and significance for whales. Can. J. Fish. Aquat. Sci. 56: 1182-1197.

Simard, Y., Lacroix, G., and Legendre, L. 1985. In situ twilight grazing rhythm during diel vertical migrations of a scattering layer of Calanus finmarchicus. Limnol. Oceanogr. 30: 598-606. 
Simard, Y., de Ladurantaye, R., and Therriault, J.-C. 1986a. Aggregation of euphausiids along a coastal shelf in an upwelling environment. Mar. Ecol. Prog. Ser. 32: 203-215.

Simard, Y., Lacroix, G., and Legendre, L. 1986b. Diel vertical migrations and nocturnal feeding of a dense coastal krill scattering layer (Thysanoessa raschi and Meganyctiphanes norvegica) in stratified surface waters. Mar. Biol. 91: 93-105.

Simard, Y., McQuinn, I., Montminy, M., Lang, C., Stevens, F., Goulet, J.-P., Lapierre, J., Beaulieu, J.-L., Landry, J., Samson, Y., and Gagné, M. 2000. CH2, Canadian hydroacoustic data analysis tool 2 user's manual (version 2.0). Can. Tech. Rep. Fish. Aquat. Sci. No. 2232.

Simard, Y., Marcotte, D., and Naraghi, K. 2003. Three-dimensional acoustic mapping and simulation of krill distribution in the Saguenay - St. Lawrence Marine Park whale feeding ground. Aquat. Living Resour. 16: 137-144.

Simmonds, E.J., and MacLennan, D.N. 2005. Fisheries acoustics: theory and practice. Blackwell Science, Oxford.

Sourisseau, M., Simard, Y., and Saucier, F.J. 2006. Krill aggregation in the St. Lawrence system, and supply of krill to the whale feeding grounds in the estuary from the gulf. Mar. Ecol. Prog. Ser. 314: $257-270$.

Spicer, J.I., Thomasson, M.A., and Stroemberg, J.-O. 1999. Possessing a poor anaerobic capacity does not prevent the diel vertical migration of Nordic krill Meganyctiphanes norvegica into hypoxic waters. Mar. Ecol. Prog. Ser. 185: 181-187.

Stanton, T.K., and Chu, D. 2000. Review and recommendations for modeling of acoustic scattering by fluid-like elongated zooplankton: euphausiids and copepods. ICES J. Mar. Sci. 57: 793-807.
Tarling, G.A. 2003. Sex-dependent diel vertical migration in northern krill Meganyctiphanes norvegica and its consequences for population dynamics. Mar. Ecol. Prog. Ser. 260: 173-188.

Tarling, G.A., Buchholz, F., and Matthews, J.B.L. 1999. The effect of lunar eclipse on the vertical migration behaviour of Meganyctiphanes norvegica (Crustacea: Euphausiacea) in the Ligurian Sea. J. Plankton Res. 21: 1475-1488.

Tarling, G.A., Jarvis, T., Emsley, S.M., and Matthews J.B.L. 2002. Midnight sinking behavior in Calanus finmarchicus: a response to satiation or krill predation? Mar. Ecol. Prog. Ser. 240: 183-194.

Thomasson, M.A., Johnson, M.L., Strömberg, J.-O., and Gaten, E. 2003. Swimming capacity and pleopod beat rate as a function of sex, size and moult stage in northern krill Meganyctiphanes norvegica. Mar. Ecol. Prog. Ser. 250: 205-213.

Welschmeyer, N.A. 1994. Fluorometric analysis of chlorophyll $a$ in the presence of chlorophyll $b$ and pheopigments. Limnol. Oceanogr. 39: 1985-1992.

Wiebe, P.H., Ashjian, G.J., Gallager, S.N., Davis, C.S., Lawson, G.L., and Copley, N. 2004. Using a high-powered strobe light to increase the catch of Antarctic krill. Mar. Biol. 144: 493502.

Zakardjian, B.A., Runge, J.A., Plourde, S., and Gratton, Y. 1999. A biophysical model of the interaction between vertical migration of crustacean zooplankton and circulation in the Lower St. Lawrence Estuary. Can. J. Fish. Aquat. Sci. 56: 2420-2432. 